\title{
Seasonal and inter-annual variations in carbon fluxes and evapotranspiration over cotton field under drip irrigation with plastic mulch in an arid region of Northwest China
}

\author{
Jie BAI ${ }^{*}$, Jin $\mathrm{WANG}^{2}$, Xi CHEN ${ }^{1}$, GePing LUO ${ }^{1}$, Hao $\mathrm{SHI}^{3}$, LongHui $\mathrm{LI}^{3}$, JunLi $\mathrm{LI}^{1}$ \\ ${ }^{1}$ State Key Laboratory of Desert and Oasis Ecology, Xinjiang Institute of Ecology and Geography, Chinese Academy of Sciences, \\ Urumqi 830011, China; \\ ${ }^{2}$ Wulanwusu Agrometeorological Experiment Station, Shihezi Meteorological Administration, Shihezi 832003, China; \\ ${ }^{3}$ Plant Functional Biology \& Climate Change Cluster, University of Technology, Sydney, NSW 2007, Australia
}

\begin{abstract}
Xinjiang is the largest semi-arid and arid region in China, and drip irrigation under plastic mulch is widely used in this water-limited area. Quantifying carbon and water fluxes as well as investigating their environmental drivers over cotton fields is critical for understanding regional carbon and water budgets in Xinjiang, the largest cotton production basin of China. In this study, an eddy covariance (EC) technique was used to measure the carbon and water fluxes of cotton field under drip irrigation with plastic mulch in the growing seasons of 2009, 2010, 2012 and 2013 at Wulanwusu Agrometeorological Experiment Station, a representative oasis cropland in northern Xinjiang. The diurnal patterns of gross primary production (GPP), net ecosystem exchange (NEE) and evapotranspiration (ET) showed obviously sinusoidal variations from June to September, while the diurnal ecosystem respiration $\left(R_{e s}\right)$ was stable between daytime and nighttime. The daytime hourly GPP and ET displayed asymptotic relationships with net solar radiation (Rnet), while showed concave patterns with raising vapor pressure deficit (VPD) and air temperature $\left(\mathrm{T}_{\mathrm{a}}\right)$. The increases in hourly GPP and ET towards the maximum occurred over half ranges of VPD and $T_{a}$. The seasonal variations of GPP, NEE and ET were close to the cotton phenology, which almost reached the peak value in July. The cumulative GPP averaged $816.2 \pm 55.0 \mathrm{~g} \mathrm{C} / \mathrm{m}^{2}$ in the growing season (from April to October), and more than half of GPP was partitioned into NEE (mean value of $-478.6 \pm 41.4 \mathrm{~g} \mathrm{C} / \mathrm{m}^{2}$ ). The mean seasonal ET was $501.3 \pm 13.9 \mathrm{~mm}$, and the mean water use efficiency (WUE) was $1.0 \pm 0.1(\mathrm{mg} \mathrm{C} / \mathrm{g} \mathrm{H} 2 \mathrm{O}) / \mathrm{d}$. The agro-ecosystem behaved as a carbon sink from squaring to harvest period, while it acted as a carbon source before the squaring time as well as after the harvest time.
\end{abstract}

Keywords: cotton; eddy covariance; net ecosystem exchange (NEE); carbon budget; water use efficiency (WUE)

Citation: Jie BAI, Jin WANG, Xi CHEN, GePing LUO, Hao SHI, LongHui LI, JunLi LI. 2015. Seasonal and inter-annual variations in carbon fluxes and evapotranspiration over cotton field under drip irrigation with plastic mulch in an arid region of Northwest China. Journal of Arid Land, 7(2): 272-284. doi: 10.1007/s40333-014-0012-x

Arid and semi-arid regions, covering about $30 \%$ of the global land surface (Asner et al., 2003), significantly contribute to global carbon and water cycles (Li et al., 2013). Compared to other desert vegetation, cropland is more heavily influenced by anthropogenic activities (e.g. irrigation, fertilization, tillage and other new technologies), thus it is one of the most active com ponents of carbon and water budgets in arid and semiarid regions (Li et al., 2011a).

Drip irrigation with mulch has been proved to reduce soil evaporation and increase crop production, thus increasing water use efficiency (WUE) in many arid and semi-arid regions (Li et al., 2004; Chakraborty et al., 2008; Hou et al., 2010; Li et al., 2011b).

*Corresponding author: Jie BAI (E-mail: baijie@ms.xjb.ac.cn)

Received 2014-03-31; revised 2014-06-20; accepted 2014-08-19

(C) Xinjiang Institute of Ecology and Geography, Chinese Academy of Sciences, Science Press and Springer-Verlag Berlin Heidelberg 2015 
Previous field experiments have indicated that plastic mulch could modify soil micro-environments such as soil temperature and moisture (Ramakrishna et al., 2006), as well as surface albedo and energy partition (Ham and Kluitenberg, 1994; Tarara and Ham, 1999). Although the improvement of crop yield and WUE under plastic mulch has been acknowledged, the carbon and water fluxes as well as their controlling factors under plastic mulch were not systematically quantified.

Cotton-producing area in Xinjiang of China tripled during the past 20 years (Statistic Bureau of Xinjiang Uygur Autonomous Region, 1990-2012). Currently, more than $50 \%$ of the national cotton production is supplied by Xinjiang, and more than $85 \%$ of the cotton fields were covered with plastic mulch in this region. Many studies have focused on the cotton yield (Wang et al., 2004), water consumption (Zhou et al., 2012) and soil carbon flux ( $\mathrm{Li}$ et al., 2011b) in Xinjiang. For example, study of Wang et al. (2004) showed that high lint percentage contributed to an increasing lint yield of cotton in Shihezi, northern Xinjiang. Partial root-zone irrigation with furrow or drip irrigation has been shown to be a highly effective irrigation method in the Fukang oasis of northern Xinjiang (Tang et al., 2005; Du et al., 2008). Drip irrigation with mulching on cotton was reported to decrease soil $\mathrm{CO}_{2}$ emission (Li et al., 2011b, 2012) and maintain stable evapotranspiration (ET) through the growing season (Zhou et al., 2012). However, there have been a few experiments on the continuously temporal variations in the carbon and water exchanges for the cotton under plastic mulching in arid regions of Xinjiang using an eddy covariance (EC) technique.

The main objectives of this study were to: (1) quantify the carbon and water fluxes using the EC technique; (2) investigate the diurnal, seasonal and inter-annual variations of carbon and water fluxes; and (3) analyze the carbon and water exchanges in response to climate factors during the growing season.

\section{Materials and methods}

\subsection{Site description}

The Wulanwusu Agrometeorological Experiment Station $\left(85^{\circ} 49^{\prime} \mathrm{E}, 44^{\circ} 17^{\prime} \mathrm{N}\right.$; $469 \mathrm{~m}$ asl) is located in the
Shihezi oasis of northern Xinjiang, China. The oasis is characterized by an arid climate with an annual mean temperature of $7.0^{\circ} \mathrm{C}$. The warmest and coldest months are July (mean $26.9^{\circ} \mathrm{C}$ ) and January (mean $-2.4^{\circ} \mathrm{C}$ ), respectively. The average annual precipitation is $210 \mathrm{~mm}$ with most occurring from April to July, and the annual pan evaporation is as high as $1,600 \mathrm{~mm}$. In the experiment station, the average bulk density of the soil is $1.30 \mathrm{~g} / \mathrm{cm}^{3}$, and the soil texture is sandy loam. The mean field capacity is 0.27 , and the soil wilting point is 0.048 in the topsoil layer of $0-50 \mathrm{~cm}$. The climate in this location is suitable for planting cotton using a single cropping system. Cotton is sowed in mid- to late-April and harvested in early or mid-October. Approximately $80 \%$ of the surface is covered by a 0.08 -mm-thick plastic film when the cotton is sowed (Zhou et al., 2012).

\subsection{Field measurements}

\subsubsection{Flux and meteorological measurements}

The $\mathrm{CO}_{2}$ flux was measured by an EC system at a height of $4.0 \mathrm{~m}$ during the cotton growing season. The system consisted of a three-dimensional (3D) sonic anemometer (CSAT3, Campbell Scientific Inc., Logan, UT, USA) and an LI-7500 open-path infrared gas analyzer (Li-COR, Inc., Lincoln, NE, USA). The data were recorded by a data logger (CR3000, Campbell Scientific Inc, Logan, UT, USA), and the sampling frequency of the EC system was $10 \mathrm{~Hz}$. Air temperature $\left(\mathrm{T}_{\mathrm{a}}\right)$ and humidity were measured using a HMP45D probe (HMP45D, Vaisala, Inc., Helsinki, Finland) at $2.0 \mathrm{~m}$ above ground level. The downward and upward short and long-wave radiation were measured with a radiometer (CNR-1, Kipp \& Zonen, Delft, the Netherlands) at $3.0 \mathrm{~m}$ above ground level. Precipitation was measured using a standard $20-\mathrm{cm}$ diameter rain gauge and the atmospheric pressure was measured using a PTB220 barometer (Vaisala, Helsinki, Finland). The wind speed and direction were measured using the EL15-1A wind speed sensor and the EL15-2D wind direction sensor (Zhonghuan TIG, Tianjin, China), respectively. Soil heat flux $(G)$ was measured with two soil-heat-flux plates (HFP01, Hukseflux, Delft, the Netherlands) at $80-\mathrm{mm}$ depth below the ground surface. Soil temperature was measured using a TCAV probe (Campbell Scientific 
Inc., Logan, UT, USA) at the depths of 20 and $60 \mathrm{~mm}$. The data for this study was recorded from January to December in 2009, 2010, 2012 and 2013.

1.2.2 Agro-management inventories and biometric measurements

Table 1 shows the development, management (irrigation and fertilization) and seed yields of cotton at Wulanwusu site during the four study years. The planting system of cotton here was bringing in one harvest a year. The lengths of the growing period were approximately $188,160,149$ and 169 days in 2009, 2010, 2012 and 2013, respectively. The densities of cotton achieved were 26.57, 28.94, 22.64 and 19.74 plants $/ \mathrm{m}^{2}$ in these four years, respectively. During the cotton growing period, drip irrigation was applied 7 to 8 times at an interval of approximately 10 days based on soil moisture. The irrigation water was mainly withdrawn from the Manas River. The soluble fertilizer was put into the drip irrigation system.

Table 1 Growing periods, managements and seed yields of cotton in the study periods

\begin{tabular}{cccccc}
\hline Year & Variety & $\begin{array}{c}\text { Planting } \\
\text { date }\end{array}$ & $\begin{array}{c}\text { Stopping date of } \\
\text { growing }\end{array}$ & $\begin{array}{c}\text { Irrigation amount } \\
(\mathrm{mm})\end{array}$ & $\begin{array}{c}\text { Nitrogen fertilization amount } \\
\left(\mathrm{kg} / \mathrm{hm}^{2}\right)\end{array}$ \\
\hline 2009 & Xinluzao No. 36 & $12 \mathrm{Apr}$ & 16 Oct & 330.0 & $\begin{array}{c}\text { Seed yield } \\
\left.(\mathrm{t} / \mathrm{hm})^{2}\right)\end{array}$ \\
2010 & Xinluzao No. 36 & $28 \mathrm{Apr}$ & 4 Oct & 409.5 & 28 \\
2012 & Xinluzao No. 46 & $17 \mathrm{Apr}$ & 6 Oct & 615.0 & 3.9 \\
2013 & Xinluzao No. 46 & $8 \mathrm{Apr}$ & $22 \mathrm{Sep}$ & 525.0 & 4.2 \\
\hline
\end{tabular}

The sample plot of leaf area index (LAI) had an area of $0.3 \mathrm{~km} \times 0.3 \mathrm{~km}$ and was located about $2 \mathrm{~km}$ west of the EC system. LAI was measured by collecting destructive plant samples. Twenty plants were randomly collected at representative stages (e.g. seedling stage, squaring stage, flowering stage and boll opening stage) during the cotton growing season in the plot. The dimensions (length and width) of all the leaves of the sampled plants were measured with a scale, and the total leaf area was calculated as the product of its length along primary vein, the maximum width and a correction coefficient of 0.75 . The LAI was then calculated as the leaf area per unit of ground area.

\subsection{Flux data treatments}

1.3.1 Flux gap-filling and net ecosystem exchange (NEE) partitioning

We applied 3D coordinate rotation and density fluctuation correction to obtain the half-hourly mean heat, water vapor and $\mathrm{CO}_{2}$ fluxes. The flux measurements were filtered to remove data spikes caused by instrument errors or inappropriate meteorological conditions for EC measurements (Vickers and Mahrt, 1997; Baldocchi, 2003; Papale et al., 2006).

Firstly, flux data was discarded if the scalar means, scalar standard deviations or flux values were outside the realistic boundaries. Secondly, the moving mean $\left(X_{\text {mean }}\right)$ and standard deviation $\left(X_{\text {sdi }}\right)$ were calculated for a moving 7-day window. The window moved one point at a time through the series. Any absolute difference between the fluxes $\left(X_{i}\right)$ and the mean $\left(X_{\text {mean }}\right)$ in this window that was more than 3 times the standard deviation of the window was flagged as a spike (Vickers and Mahrt, 1997). The value was flagged as a spike if $\left|X_{i}-X_{\text {mean }}\right| \geq 3 \times X_{\text {sdi. }}$.

The flux data processes, including gap filling and net ecosystem exchange (NEE) partitioning, were carried out by the EC gap-filling \& flux-partitioning tool from the Biogeochemical Model-Data Integration Group (MDI-BGC; http://www.bgc-jena.mpg.de/ $\sim$ MDIwork/ eddyproc/). The gap-filling algorithm for half-hourly fluxes and meteorological data was followed by Reichstein et al. (2005), considering both the co-variation of fluxes with meteorological variables and the temporal auto-correlation of the fluxes. After gap-filling was achieved, the NEE was partitioned into the gross primary production (GPP) and ecosystem respiration $\left(\mathrm{R}_{\mathrm{es}}\right)$ according to the definition equation $\mathrm{NEE}=\mathrm{R}_{\mathrm{es}}-\mathrm{GPP}$. A negative $\mathrm{NEE}$ value means that the ecosystem behaves as a carbon sink $\left(\mathrm{GPP}>\mathrm{R}_{\mathrm{es}}\right)$, and a positive value means that the ecosystem behaves as a carbon source $\left(\mathrm{GPP}<\mathrm{R}_{\mathrm{es}}\right)$. The algorithm for the NEE partitioning was used by a hyperbolic light response curve which was modified by the temperature limitation on respiration and vapor pressure deficit (VPD) limitation on photosynthesis 
(Lasslop et al., 2010).

\subsubsection{Energy balance closure and footprint area}

The energy balance was examined for 'closure' by checking the equality of the sum of latent heat (LE) and sensible heat $(\mathrm{H})$ to the available energy of net solar radiation $\left(\mathrm{R}_{\text {net }}\right)$ minus $\mathrm{G}$ at Wulanwusu site (Fig. 1). The slope and intercept of the linear regression between the observed $\mathrm{LE}+\mathrm{H}$ and $\mathrm{R}_{\text {net }}-\mathrm{G}$ was 0.53 and $11.88 \mathrm{~W} / \mathrm{m}^{2}$, respectively. The regression coefficient $\left(R^{2}\right)$ of the observed $\mathrm{LE}+\mathrm{H}$ and $\mathrm{R}_{\text {net }}-\mathrm{G}$ was 0.81 .

The slope value $(0.53)$ at our study site was lower than that reported at other sites of the FLUXNET

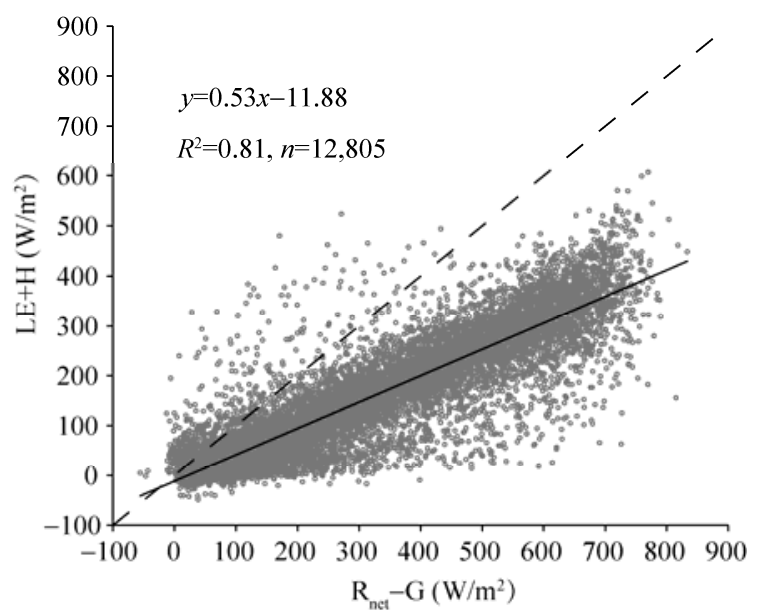

Fig. 1 Relationship between $\mathrm{LE}+\mathrm{H}$ and $\mathrm{R}_{\text {net }}-\mathrm{G}$ at Wulanwusu station. LE, latent heat; $H$, sensible heat; $R_{\text {net }}$, net solar radiation; $\mathrm{G}$, soil heat flux.

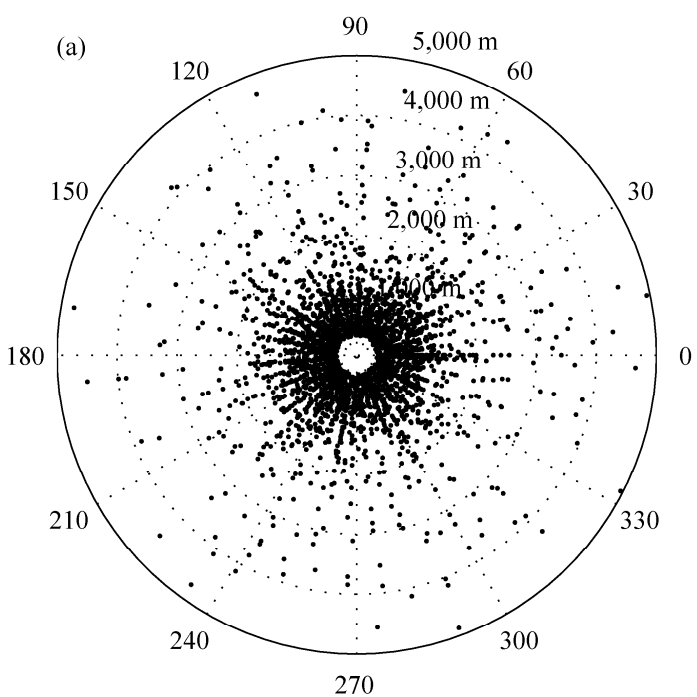

network (Wilson et al., 2002; Li et al., 2005), and showed an incomplete energy balance closure. The major reason for this was that the energy stored inside the film mulching was not considered in the energy balance (Zhou et al., 2012). The fetch length ranged from 200 to $5,000 \mathrm{~m}$ under stable conditions while it ranged $0-500 \mathrm{~m}$ under unstable conditions (Fig. 2). The result of footprint analysis in our study was similar to that in Fukang site (Li et al., 2013) which was nearby Wulanwusu site.

\subsubsection{Response functions of GPP and ET}

The functional forms of GPP and ET to $\mathrm{R}_{\text {net, }}$ VPD and $T_{a}$ in this study were taken from Whitley et al. $(2008,2012)$. The $\mathrm{R}_{\text {net }}$ responses in GPP or ET can be described by Eq. 1 .

$$
Y=A \times \frac{X}{X+g r k} \text {. }
$$

Where, $A$ is the light saturation GPP $\left(\mathrm{GPP}_{\max }\right)$ or ET ( $\left.\mathrm{ET}_{\max }\right), X$ is the $\mathrm{R}_{\text {net, }}$, and $g k r$ is the rate of change. The functional form of GPP or ET to VPD is:

$$
Y=B \times \exp \left(-\frac{K_{D 1} \times\left(X-K_{D 3}\right)^{2}}{\left(X+K_{D 2}\right)}\right) .
$$

Where, $B$ is the maximum value of GPP (GPP $\max$ ) or ET (ET $\left.T_{\max }\right), X$ is the VPD, $K_{D 1}$ and $K_{D 2}$ describe the shape of the response curve, and $K_{D 3}$ describes the value of optimal VPD at which GPP or ET is maximized. The functional form of GPP or ET to $T_{a}$ is expressed as Eq. 3.

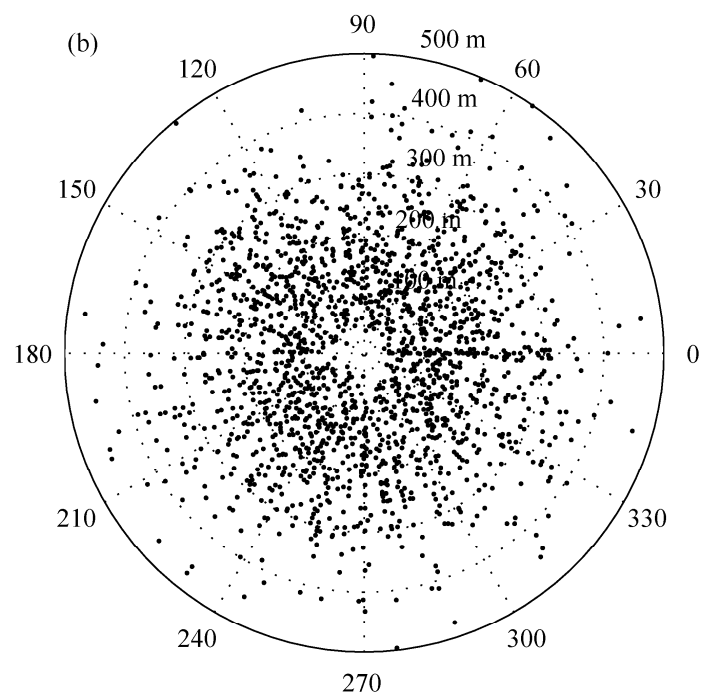

Fig. 2 Footprint areas of the observed fluxes under stable (a) and unstable (b) conditions at Wulanwusu station 


$$
Y=C \times \exp \left(-\frac{K_{T 1} \times\left(X-K_{T 3}\right)^{2}}{\left(X+K_{T 2}\right)}\right) .
$$

Where, $C$ is the maximum value of GPP $\left(\mathrm{GPP}_{\max }\right)$ or ET (ET $\left.T_{\text {max }}\right), X$ is the $\mathrm{T}_{\mathrm{a}}, K_{T 1}$ and $K_{T 2}$ describe the shape of the response curve, and $K_{T 3}$ describes the value of optimal $\mathrm{T}_{\mathrm{a}}$ at which GPP or ET is maximized.

\section{Results}

\subsection{Seasonal variations of environmental variables}

The mean values of $R_{\text {net }}$ from April to October in 2012 and 2013 (168 and $167 \mathrm{~W} / \mathrm{m}^{2}$, respectively) were much lower than those in 2009 and 2010 (178 and $181 \mathrm{~W} / \mathrm{m}^{2}$, respectively; Fig. $3 a)$. The peak values of $R_{\text {net }}$ over the four periods occurred in June and July.

The mean values of $\mathrm{T}_{\mathrm{a}}$ from April to October were $18.7^{\circ} \mathrm{C}, 18.5^{\circ} \mathrm{C}, 19.9^{\circ} \mathrm{C}$ and $18.7^{\circ} \mathrm{C}$ in 2009,2010 , 2012 and 2013, respectively (Fig. 3b). The respective mean $\mathrm{T}_{\mathrm{a}}$ of 2009,2010 and 2013 was close to the long-time mean value of $18.5^{\circ} \mathrm{C}$ during $1950-2008$. However, mean $\mathrm{T}_{\mathrm{a}}$ in 2012 was $1.4^{\circ} \mathrm{C}$ higher than the normal level. The monthly mean maximum temperature was around $25.0^{\circ} \mathrm{C}$.

The mean daily VPD from April to October in 2012 $(1.4 \mathrm{kPa})$ was significantly higher than that in the other three years $(1.2 \mathrm{kPa}$ in 2010 , as well as $1.1 \mathrm{kPa}$ in 2009 and 2013; Fig. 3c). The result showed that the evaporative demand in 2012 was the highest. The monthly mean VPD of the four years all reached peak values in June, especially in 2012 and 2010 with the higher values of 1.9 and $1.8 \mathrm{kPa}$, respectively.

The seasonal precipitation during the study periods showed two kinds of hydrological years (Fig. 3d). The study year of 2012 was extremely dry with a total precipitation of $62.5 \mathrm{~mm}$ from April to October, which was $58.3 \%$ below the long-term mean of $150 \mathrm{~mm}$

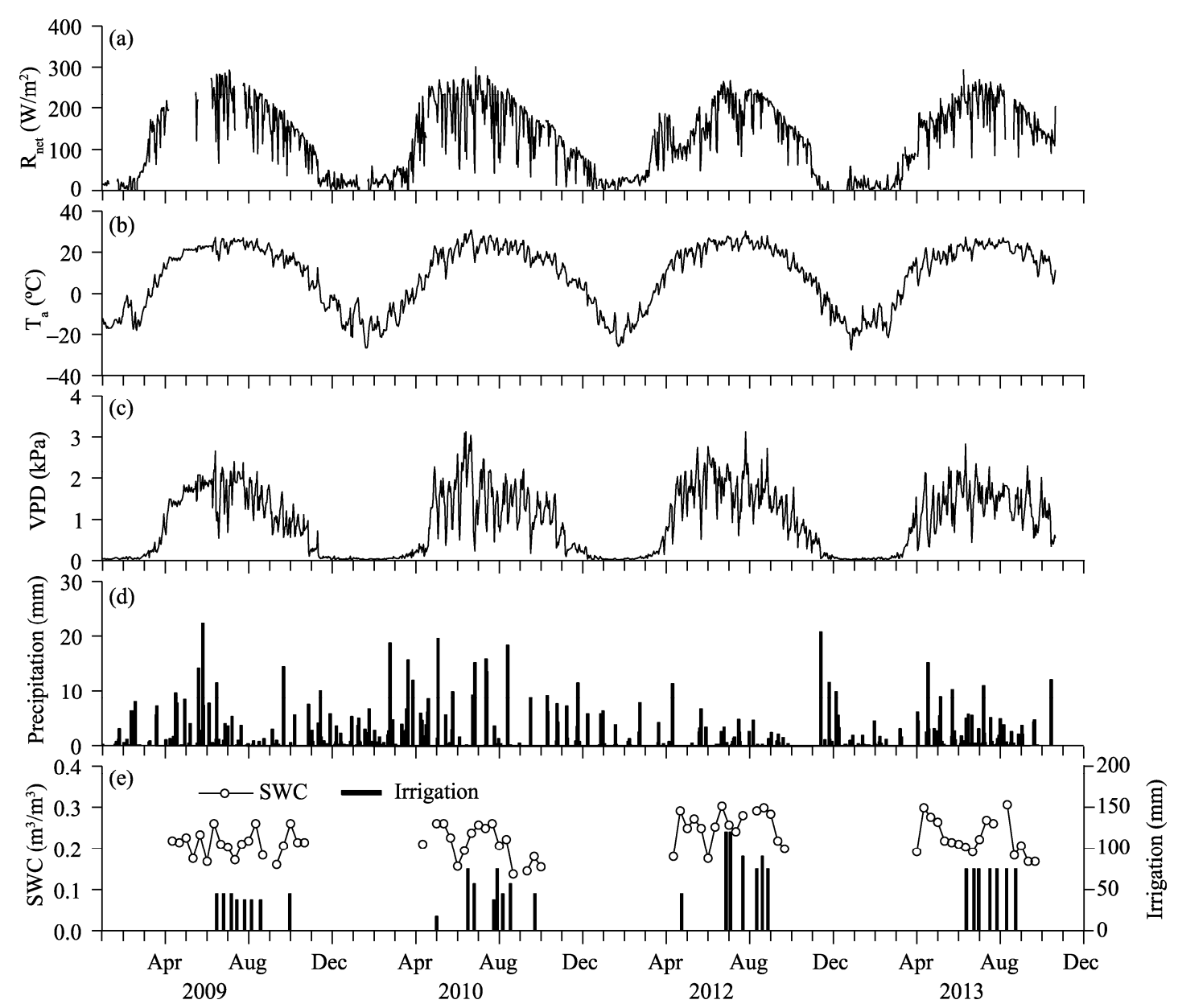

Fig. 3 Daily measurements for climate factors (a-d) and SWC and irrigation (e) at Wulanwusu station in $2009,2010,2012$ and 2013. $\mathrm{R}_{\text {net }}$, net solar radiation; $\mathrm{T}_{\mathrm{a}}$, air temperature; VPD, vapor pressure deficit; SWC, soil water content $(0-50 \mathrm{~cm})$. 
during 1958-2008. The study years of 2009, 2010 and 2013 were the normal hydrological years with the total precipitations of $163.2,190.5$ and $157.5 \mathrm{~mm}$ from April to October, respectively; and these three values were $8.8 \%, 27.0 \%$ and $5.0 \%$ above the long-term mean, respectively. Precipitation was generally distributed in April to July, and was relatively lower in August to October. Monthly precipitations were higher in May 2009, May 2010, May 2012 and July 2013, with the values of 53.2, 39.7, 16.0 and $36.5 \mathrm{~mm}$, respectively.

The mean values of SWC at the depth of $0-50 \mathrm{~cm}$ maintained at steady levels of $0.21 \pm 0.01,0.20 \pm 0.04$, $0.25 \pm 0.03$ and $0.23 \pm 0.04 \mathrm{~m}^{3} / \mathrm{m}^{3}$ in $2009,2010,2012$ and 2013, respectively (Fig. 3e). Drip irrigation supplied sufficient water despite the uneven seasonal distribution of precipitation during the cotton growing season. In particular, precipitation from June to $\mathrm{Au}-$ gust in 2012 was extremely low with the monthly precipitation less than $15 \mathrm{~mm}$. However, SWC during this arid period rarely fell below the mean level because of sufficient irrigation during these months. Irrigation amount was higher than the total precipitation during this period, so irrigation played a more important role on SWC in the cropland of arid regions.

\subsection{Diurnal variations of carbon and water fluxes}

The diurnal variations of carbon and water fluxes from May to October are shown in Fig. 4. The mean diurnal GPP and NEE in each month followed an obvious sinusoidal dynamic, but the mean diurnal $\mathrm{R}_{\mathrm{es}}$ kept a horizontal level during the whole growing season (Figs. $4 \mathrm{a}-\mathrm{f}$ ). The diurnal values of GPP and NEE were from -0.5 to 21.6 and -18.7 to $2.7 \mu \mathrm{mol} /\left(\mathrm{m}^{2} \cdot \mathrm{s}\right)$, respectively; while the diurnal $R_{\text {es }}$ varied from 0.6 to $3.5 \mu \mathrm{mol} /\left(\mathrm{m}^{2} \cdot \mathrm{s}\right)$. The mean diurnal $R_{\text {es }}$ remained stable between daytime and nighttime due to the plastic mulch could prevent soil temperature from falling during the nighttime. Both of the maximum GPP and minimum NEE occurred at everyday about 14:00 in each month. The maximum mean diurnal value of GPP was $21.6 \mu \mathrm{mol} /\left(\mathrm{m}^{2} \cdot \mathrm{s}\right)$ in July, while the values of NEE and $R_{\text {es }}$ were -18.6 and $3.0 \mu \mathrm{mol} /\left(\mathrm{m}^{2} \cdot \mathrm{s}\right)$, respectively. This illustrated that the diurnal NEE accounted for a greater portion of GPP than $\mathrm{R}_{\mathrm{es}}$ in plastic mulched cotton field.

The mean diurnal ET also followed an obvious sinusoidal dynamic in each month (Figs. $4 \mathrm{~g}-1$ ). The peak value of diurnal ET occurred at everyday about 15:00 in each month. The maximum mean diurnal ET of each month increased from May and reached the peak value of 0.49 $\mathrm{mm}$ in July, and then decreased from August to October.

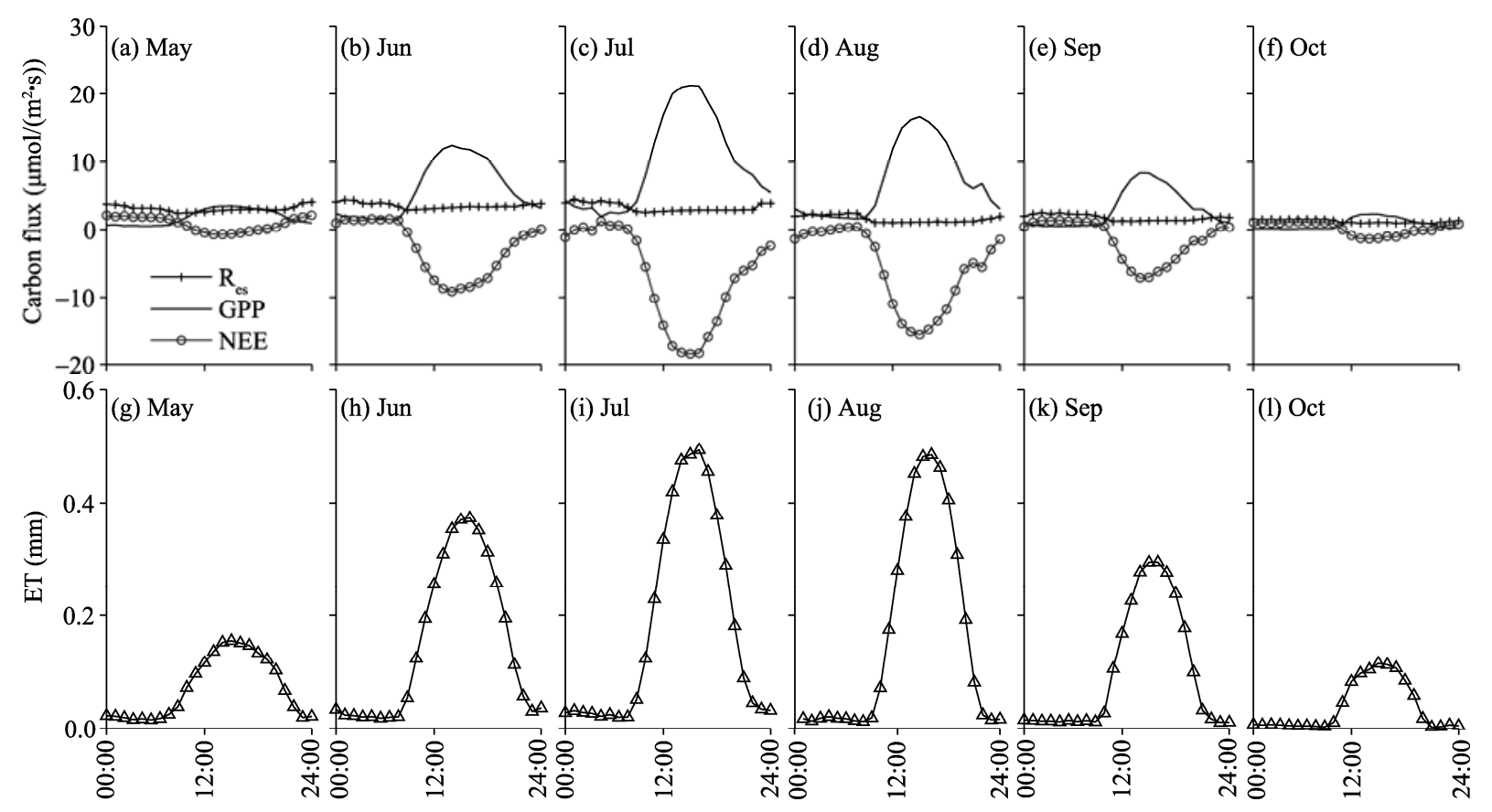

Fig. 4 Mean diurnal variations of carbon fluxes (a-f) and ET ( $g-l)$ from May to October. Res, ecosystem respiration; GPP, gross primary production; NEE, net ecosystem exchange; ET, evapotranspiration. 


\subsection{Seasonal and inter-annual variations in carbon and water budgets}

The dynamics of GPP and NEE showed remarkable variations and closely followed the development of LAI (Figs. 5a and b). When the LAI was less than 1 $\mathrm{m}^{2} / \mathrm{m}^{2}$ before the squaring time in early July, the value of daily $R_{\text {es }}$ increased quickly than GPP, so the mean value of NEE $\left(0.1-0.5 \mathrm{~g} \mathrm{C} /\left(\mathrm{m}^{2} \cdot \mathrm{d}\right)\right)$ was positive and the agro-ecosystem acted as a carbon source during the early growing season. After the leaf was large enough to provide canopy closure, GPP of the four study periods rapidly reached the maximum values of 11.0-15.7 $\mathrm{g} \mathrm{C} /\left(\mathrm{m}^{2} \cdot \mathrm{d}\right)$ in mid- or late-July, corresponding to the peak values of LAI. Afterward, GPP decreased following the decreasing LAI. The maximum values of $\mathrm{R}_{\mathrm{es}}\left(4.3-5.0 \mathrm{~g} \mathrm{C} /\left(\mathrm{m}^{2} \cdot \mathrm{d}\right)\right)$ of these four periods occurred earlier than those of GPP, but the mean value of $R_{e s}$ was smaller than that of GPP. Thus, NEE of the four study periods reached the minimum values of -9.0 to $11.7 \mathrm{~g} \mathrm{C} /\left(\mathrm{m}^{2} \cdot \mathrm{d}\right)$ near the days when GPP were at the peaks, and the agro-ecosystem acted as a strong carbon sink in the major growing season (May-September). After the harvest time (when plastic mulch was removed), GPP was nearly zero and $\mathrm{R}_{\mathrm{es}}$ was greater than zero, thus NEE became positive. The cumulated value of NEE had two positive periods: one was from planting to squaring stage (value of $45.7 \pm 15.6$ $\mathrm{g} \mathrm{C} / \mathrm{m}^{2}$ ) and another was from harvest time to the end of the year (value of $43.8 \pm 8.6 \mathrm{~g} \mathrm{C} / \mathrm{m}^{2}$ ). The mean total GPP in the growing season was $816.2 \pm 55.0 \mathrm{~g} \mathrm{C} / \mathrm{m}^{2}$, and about $41 \%$ and $59 \%$ of the total GPP were partitioned into $\mathrm{R}_{\mathrm{es}}$ and NEE, respectively.

The seasonal and inter-annual patterns of ET closely matched those of GPP (Figs. 5b and c). ET increased quickly from the squaring time as a result of rapid plant growth up until July. However, there was a rapid decrease in ET from late-July, following the senescence of the plant. The peak values of ET were

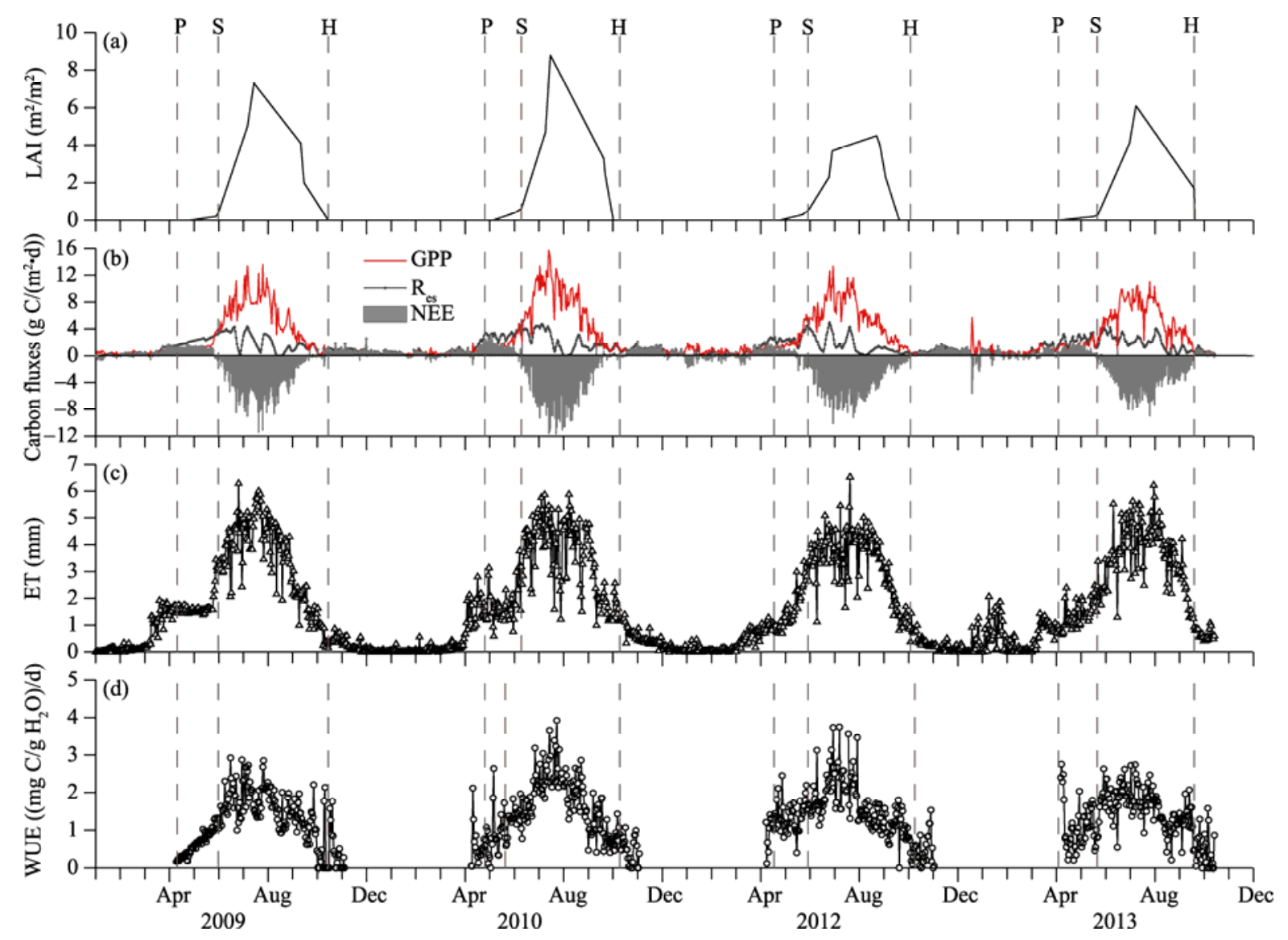

Fig. 5 Seasonal and inter-annual variations of LAI (a), daily carbon fluxes, (b), ET, (c), and WUE (d), in 2009, 2011, 2012 and 2013. LAI, leaf area index; WUE, water use efficiency; $\mathrm{P}$, date of planting; $\mathrm{S}$, date of squaring; $\mathrm{H}$, date of harvest. 
6.3, 5.9, 6.5 and $6.2 \mathrm{~mm}$ in 2009, 2010, 2012 and 2013, respectively. The maximum ET occurred in 2012 because of the highest irrigation amount. The mean annual ET at Wulanwusu site was $574.4 \pm 20.9 \mathrm{~mm}$. The mean cumulative ET during the cotton growing season was $501.3 \pm 13.9 \mathrm{~mm}$, accounting for $87 \%$ of the annual water consumption. ET in the cotton growing season was 3.5 times higher than the corresponding cumulative precipitation (Table 2). A large amount of irrigation (over 3 times of total precipitation on aver- age) has been supplied to meet the demands of cotton growing in this arid region. For example, the total precipitation in the dry year of 2012 was only half of that in the normal hydrological years, but the total ET in this dry year remained stable with a level of 491.5 $\mathrm{mm}$ due to the highest amount of irrigation (615.0 $\mathrm{mm})$. The seasonal total ET showed a significant relationship with the $\mathrm{R}_{\text {net }}$ because the SWC was maintained stable under sufficient irrigation and plastic mulching.

Table 2 Values of carbon fluxes (GPP, $R_{\text {es }}$ and NEE), ET and hydrometeorological elements (WUE, $R_{\text {net }}, T_{a}, V P D, P$ and SWC) in the growing seasons of 2009, 2010, 2012 and 2013

\begin{tabular}{ccccccccccc}
\hline Year & $\begin{array}{c}\mathrm{GPP} \\
\left(\mathrm{g} \mathrm{C}^{2}\right)\end{array}$ & $\begin{array}{c}\mathrm{R}_{\mathrm{es}} \\
\left(\mathrm{g} \mathrm{C}^{2}\right)\end{array}$ & $\begin{array}{c}\mathrm{NEE} \\
\left(\mathrm{g} \mathrm{C}^{2} \mathrm{~m}^{2}\right)\end{array}$ & $\begin{array}{c}\mathrm{ET} \\
(\mathrm{mm})\end{array}$ & $\begin{array}{c}\mathrm{WUE} \\
\left(\left(\mathrm{mg} \mathrm{C} / \mathrm{g} \mathrm{H}_{2} \mathrm{O}\right) / \mathrm{d}\right)\end{array}$ & $\begin{array}{c}\mathrm{R}_{\text {net }} \\
\left(\mathrm{W} / \mathrm{m}^{2}\right)\end{array}$ & $\begin{array}{c}\mathrm{T}_{\mathrm{a}} \\
\left({ }^{\circ} \mathrm{C}\right)\end{array}$ & $\begin{array}{c}\mathrm{VPD} \\
(\mathrm{kPa})\end{array}$ & $\begin{array}{c}\mathrm{P} \\
(\mathrm{mm})\end{array}$ & $\begin{array}{c}\mathrm{SWC} \\
\left(\mathrm{m}^{3} / \mathrm{m}^{3}\right)\end{array}$ \\
\hline 2009 & 796.7 & 346.7 & -450.0 & 512.7 & 0.8 & 178.5 & 18.7 & 1.2 & 163.2 & 0.21 \\
2010 & 900.1 & 395.8 & -504.3 & 517.0 & 1.0 & 181.0 & 18.5 & 1.5 & 190.8 & 0.20 \\
2012 & 820.0 & 288.1 & -531.9 & 491.5 & 1.1 & 168.3 & 19.9 & 1.6 & 62.5 & 0.25 \\
2013 & 747.9 & 319.7 & -428.2 & 484.0 & 0.9 & 167.8 & 18.7 & 1.2 & 157.5 & 0.23 \\
Mean & $816.2 \pm 55.0$ & $337.6 \pm 39.5$ & $-478.6 \pm 41.4$ & $501.3 \pm 13.9$ & $1.0 \pm 0.1$ & $173.9 \pm 5.9$ & $19.0 \pm 0.6$ & $1.4 \pm 0.2$ & $143.5 \pm 48.4$ & $0.22 \pm 0.02$ \\
\hline
\end{tabular}

Note: GPP, gross primary production; $\mathrm{R}_{\mathrm{es}}$, ecosystem respiration; NEE, net ecosystem exchange; ET, evapotranspiration; WUE, water use efficiency; $\mathrm{R}_{\text {net }}$, net solar radiation; $\mathrm{T}_{\mathrm{a}}$, air temperature; $\mathrm{VPD}$, vapor pressure deficit; $\mathrm{P}$, precipitation; $\mathrm{SWC}$, soil water content $(0-50 \mathrm{~cm})$.

\subsection{Seasonal and inter-annual variations in WUE}

The WUE can be calculated using the ratio of GPP to the corresponding ET. In this study, GPP and ET were both directly measured using the EC technique. ET was calculated as the ratio of LE flux to the LE of water vaporization $(\lambda=2.45 \mathrm{MJ} / \mathrm{kg})$. Seasonal pattern of WUE in the cotton growing season was similar to that of GPP and ET (Fig. 5d). Before the squaring time, WUE was lower due to the small value of LAI. After the squaring time, WUE increased quickly and kept a higher value until July because the increment of photosynthetic rate was higher than that of ET. The maximum daily values of WUE in the four periods ranged from 2.1 to $3.3\left(\mathrm{mg} \mathrm{C} / \mathrm{g} \mathrm{H}_{2} \mathrm{O}\right) / \mathrm{d}$. Thereafter, WUE declined and was close to zero at harvest time.

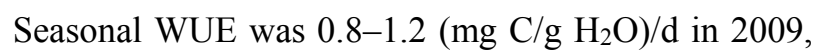
2010, 2012 and 2013.

\subsection{Responses of GPP and ET to climate variables}

A comparison of the responses of hourly GPP and ET to $R_{\text {net, }}$ VPD and $T_{a}$ in the study periods is presented in Fig. 6. The data was selected in daytime $\left(R_{\text {net }}>10 \mathrm{~W} / \mathrm{m}^{2}\right)$ and in the major growing season (from May to September). The boundary curves displayed signifycant asymptotic responses of GPP and ET to the increased $\mathrm{R}_{\text {net }}$ (Figs. 6a and d). With the increasing $\mathrm{R}_{\text {net, }}$, the GPP and ET both increased from zero to the maximum value asymptotically, and showed no saturation occurring before $R_{\text {net }}$ reached $900 \mathrm{~W} / \mathrm{m}^{2}$. The estimated maximal values for GPP and ET were $28.6 \mu \mathrm{mol} /\left(\mathrm{m}^{2} \cdot \mathrm{s}\right)$ and $1.0 \mathrm{~mm}$, respectively; while the measured maximal values were $27.8 \mu \mathrm{mol} /\left(\mathrm{m}^{2} \cdot \mathrm{s}\right)$ and $0.8 \mathrm{~mm}$, respectively. The change rate between ET and $\mathrm{R}_{\text {net }}$ was greater than that between GPP and $\mathrm{R}_{\text {net }}$, reflected by the greater $g k r$ value in the former response curve (Table 3 ).

The responses of GPP and ET to increased VPD showed similar concave curves (Figs. $6 \mathrm{~b}$ and e). With the increasing VPD, GPP increased firstly and reached the maximum over a nearly half range of VPD (0-2.6 kPa), and then it declined (Table 3). ET increased as VPD increased up to about $3.1 \mathrm{kPa}$, and then it declined despite VPD increasing further (Table 3). The optimum VPD for ET was higher than that for GPP.

The responses of GPP and ET to $T_{a}$ also showed concave shapes (Figs. 6c and f). GPP and ET increased from zero to the maximum within the larger ranges of $\mathrm{T}_{\mathrm{a}}\left(0-29.8^{\circ} \mathrm{C}\right.$ and $0-32.3^{\circ} \mathrm{C}$, respectively; 

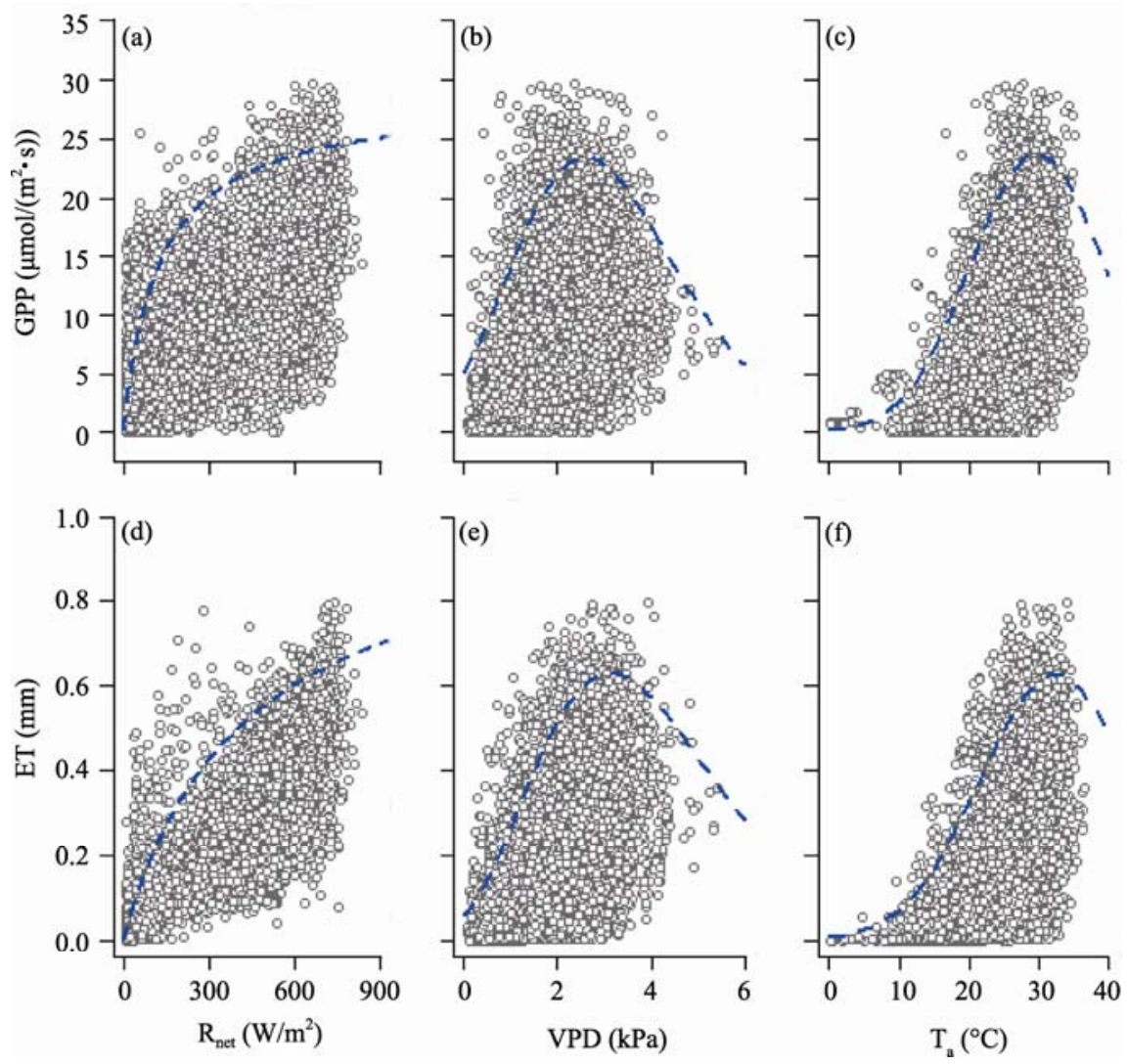

Fig. 6 Seasonal responses of hourly values of GPP and ET to $R_{\text {net }}(a$ and $d)$, VPD (b and e) and $T_{a}$ (c and f) in the cotton growing seasons of 2009, 2010, 2012 and 2013. Blue lines shown are the 95\% confidence boundaries for cotton.

Table 3 Estimated parameters in functional responses of hourly GPP and ET to $\mathrm{R}_{\text {net }}(A$ and $g k r)$, VPD $\left(B, K_{D_{1}}, K_{D_{2}}\right.$ and $\left.K_{D_{3}}\right)$ and $\mathrm{T}_{\mathrm{a}}(C$, $K_{T_{1}}, K_{T_{2}}$ and $\left.K_{T_{3}}\right)$

\begin{tabular}{|c|c|c|c|c|c|c|c|c|c|}
\hline \multicolumn{2}{|c|}{ GPP to $R_{\text {net }}$} & \multicolumn{4}{|c|}{ GPP to VPD } & \multicolumn{4}{|c|}{ GPP to $T_{a}$} \\
\hline$A$ & $g k r$ & $B$ & $K_{D 1}$ & $K_{D 2}$ & $K_{D 3}$ & $C$ & $K_{T 1}$ & $K_{T 2}$ & $K_{T 3}$ \\
\hline $\begin{array}{l}28.6 \\
(0.7)\end{array}$ & $\begin{array}{l}127.1 \\
(13.9)\end{array}$ & $\begin{array}{l}23.4 \\
(0.2)\end{array}$ & $\begin{array}{c}1.6 \\
(0.8)\end{array}$ & $\begin{array}{c}7.0 \\
(4.0)\end{array}$ & $\begin{array}{c}2.6 \\
(0.0)\end{array}$ & $\begin{array}{l}23.8 \\
(0.3)\end{array}$ & $\begin{array}{l}2,954.9 \\
(291.4)\end{array}$ & $\begin{array}{c}535,821 \\
6(0.0)\end{array}$ & $\begin{array}{l}29.8 \\
(0.5)\end{array}$ \\
\hline \multicolumn{2}{|c|}{ ET to $R_{\text {net }}$} & \multicolumn{4}{|c|}{ ET to VPD } & \multicolumn{4}{|c|}{ ET to $T_{a}$} \\
\hline A & $g k r$ & $B$ & $K_{D 1}$ & $K_{D 2}$ & $K_{D 3}$ & C & $K_{T 1}$ & $K_{T 2}$ & $K_{T 3}$ \\
\hline $\begin{array}{c}1.0 \\
(0.0)\end{array}$ & $\begin{array}{l}430.6 \\
(33.4)\end{array}$ & $\begin{array}{c}0.6 \\
(0.0)\end{array}$ & $\begin{array}{c}0.9 \\
(0.2)\end{array}$ & $\begin{array}{c}3.8 \\
(1.1)\end{array}$ & $\begin{array}{c}3.1 \\
(0.0)\end{array}$ & $\begin{array}{c}0.6 \\
(0.0)\end{array}$ & $\begin{array}{l}95.3 \\
(5.3)\end{array}$ & $\begin{array}{c}220,86.7 \\
(0.0)\end{array}$ & $\begin{array}{l}32.3 \\
(0.5)\end{array}$ \\
\hline
\end{tabular}

Note: The standard error $\left(\sigma_{\mathrm{sd}}\right)$ is given as a fraction of its respective parameter value in the bracket.

Table 3). Afterwards, GPP and ET declined and it was noted that there was a relatively smaller increase in $\mathrm{T}_{\mathrm{a}}$. The optimum $\mathrm{T}_{\mathrm{a}}$ for $\mathrm{ET}$ was also higher than that for GPP.

\section{Discussion}

\subsection{Carbon and water budgets in plastic mulched cotton field}

The ratio of accumulated $\mathrm{R}_{\mathrm{es}}$ to GPP was averaged $41 \%$, while the ratio of accumulated NEE to GPP av- eraged 59\% (Table 4). Compared with other agro-ecosystems in the literatures, the averaged ratio of accumulated $R_{\text {es }}$ to GPP on mulched cotton was significantly lower than that on non-mulched crops (T-test, $P<0.001$ ), whereas the ratio of accumulated NEE to GPP on mulched cotton was significantly greater than that on non-mulched crops.

Field researches reported that mulching could modify soil respiration ( $\mathrm{Li}$ et al., 2011b; Liu, 2013) and carbon flux (Duiker and Lal, 2000). Using the method of a closed opaque chamber, Li et al. (2012) reported 
Table 4 Comparsions of GPP, NEE, $R_{\text {es }}$ and carbon partitions between mulched cotton in the Wulanwusu site and non-mulched crops in the other areas

\begin{tabular}{|c|c|c|c|c|c|c|c|c|c|}
\hline $\begin{array}{l}\text { Crop } \\
\text { species }\end{array}$ & Site & $\begin{array}{c}\text { GPP } \\
\left({\left.\mathrm{g} \mathrm{C} / \mathrm{m}^{2}\right)}\right.\end{array}$ & $\begin{array}{c}\mathrm{NEE} \\
\left({\left.\mathrm{g} \mathrm{C} / \mathrm{m}^{2}\right)}\right.\end{array}$ & $\begin{array}{c}\mathrm{R}_{\mathrm{es}} \\
\left(\mathrm{g} \mathrm{C} / \mathrm{m}^{2}\right)\end{array}$ & $\begin{array}{c}\text { NEE/GPP } \\
(\%)\end{array}$ & $\begin{array}{c}\mathrm{R}_{\mathrm{es}} / \mathrm{GPP} \\
(\%)\end{array}$ & $\begin{array}{c}\text { Mulch or } \\
\text { non-mulch }\end{array}$ & Growing period & Source \\
\hline \multirow[t]{2}{*}{ Cotton } & Wulanwusu of China & 816.2 & -478.6 & 336.7 & 59.0 & 41.0 & Yes & Apr-Oct, 2009-2010 & This study \\
\hline & Lonzée of Belgium & $1,630.0$ & -680.0 & 950.0 & 41.7 & 58.3 & No & $\begin{array}{l}\text { Nov-Aug, } \\
\text { 2004-2007 }\end{array}$ & $\begin{array}{l}\text { Aubinet et al., } \\
2009\end{array}$ \\
\hline \multirow{5}{*}{$\begin{array}{l}\text { Winter } \\
\text { wheat }\end{array}$} & Weishan of China & 956.0 & -354.0 & 602.0 & 37.0 & 63.0 & No & Nov-Jun, 2005-2009 & Lei et al., 2010 \\
\hline & Changwu of China & 544.8 & -241.0 & 303.8 & 44.2 & 55.8 & No & Nov-Jun, 2008-2010 & Wang et al., 2013 \\
\hline & Lamasquère of France & 950.0 & -350.0 & 600.0 & 36.8 & 63.2 & No & 2006 & Li et al., 2011a \\
\hline & Weishan of China & 876.0 & -222.0 & 654.0 & 25.3 & 74.7 & No & Jun-Oct, 2007-2008 & Lei et al., 2010 \\
\hline & Yinke of China & $1,567.0$ & -626.0 & 941.0 & 39.9 & 60.1 & No & 2008-2009 & Wang et al., 2012 \\
\hline \multirow[t]{3}{*}{ Maize } & Nebraska of USA & $1,744.0$ & -590.0 & $1,154.0$ & 33.8 & 66.2 & No & May-Oct, 2002 & Suyker et al., 2005 \\
\hline & Klingenberg of Germany & $1,000.0$ & -200.0 & 800.0 & 20.0 & 80.0 & No & 2007 & Li et al., 2011a \\
\hline & Langerak of Netherlands & $1,400.0$ & -350.0 & $1,050.0$ & 25.0 & 75.0 & No & 2005 & Li et al., 2011a \\
\hline
\end{tabular}

Note: NEE/GPP, the ratio of NEE to GPP; $\mathrm{R}_{\mathrm{es}} / \mathrm{GPP}$, the ratio of $\mathrm{R}_{\mathrm{es}}$ to GPP.

that plastic mulch decreased $89 \mathrm{~g} \mathrm{C} / \mathrm{m}^{2}$ soil heterotrophic respiration $\left(\mathrm{R}_{\mathrm{h}}\right)$ and increased $340 \mathrm{~g} \mathrm{C} / \mathrm{m}^{2}$ accumulated NEE in a cotton field of Fukang, nearby our study site, in the 2009-2010 growing season. The impacts of mulching on soil respiration differed over different field observations due to varying soil properties, mulched materials, crop types and measurement methods. The annual carbon emission of the mulched Satsuma (900 g C/m $\mathrm{m}^{2}$ ) was less than the non-mulched carbon emission (1,500 g C/m² ; Okuda et al., 2007). In the Loess Plateau of China, plastic mulch obviously increased soil temperature and enhanced soil respiration for maize (Liu et al., 2013). However, Li et al. (2004) found that soil respiration for the mulched maize was lower than that for the non-mulched maize in the growing season (130 days after planting). The plastic mulch was also reported to increase the photosynthesis rate of cotton by $6.8 \%$ and plant biomass of cotton by $9.9 \%$ in the Yellow River delta (Dong et al., 2009).

The 4-year average daily value of ET $(2.8 \mathrm{~mm})$ in our study was lower than that reported over non-mulched practices in the major cotton production areas of arid regions such as Uzbekistan $(5.8 \mathrm{~mm}$; Ibragimov et al., 2007), Turkey (6.3 mm; Dağdelen et al., 2009), Syria (5.9 mm; Oweis et al., 2011) and California of the USA (6.6 mm; Grismer, 2002).

\subsection{Primary climate drivers of seasonal GPP and ET}

As $R_{\text {net }}$ increased, GPP and ET increased asymptotically from zero to the maximum. The observed pat- terns in the responses of GPP and ET to $\mathrm{R}_{\text {net }}$ in this study compared well with those in the study of Williams et al. (1998). At the low levels of incident radiation (from 100 to $400 \mathrm{~W} / \mathrm{m}^{2}$ ), energy supply limits GPP and ET; while at the high levels of radiation (above $400 \mathrm{~W} / \mathrm{m}^{2}$ ), other factors such as stomatal conductance, soil moisture and VPD limit GPP and ET (Law et al., 2002; Whitley et al., 2011). The declines of soil moisture in the upper soil layers were associated with the declines of stomatal conductance $\left(g_{s}\right)$ and photosynthetic rate (Hutmacher and Krieg, 1983; Williams et al., 1998). However, plastic mulch and sufficient irrigation retained the soil moisture, therefore soil water was not the limiting factor on cotton growth in arid regions (Zhou et al., 2012).

The responses of GPP and ET to increasing VPD were more complex than those to increasing $R_{\text {net }}$. At the lower ranges of VPD (VPD $\leq 2.6 \mathrm{kPa}$ ), increasing VPD resulted in the evaporative demand and stomatal limitation to carbon fixation increasing (Williams et al., 1998; Whitley et al., 2008). However, at the higher ranges of VPD (VPD $>2.6 \mathrm{kPa}$ ), water supply was no longer meeting the atmospheric demands and the $g_{s}$ closed, so that ET and GPP declined (Yong et al., 1997). The above photosynthetic processes of cotton were comparable to those of stomatal behavior observed at the leaf scale (Hutmacher and Krieg, 1983; Monteith 1995; Ko and Piccinni, 2009). The threshold of 2.6-3.1 kPa in VPD observed in the present study was at a relatively higher level comparing with the savannas in Australia (Whitley et al., 2011) and the 
rain forest in Brazil (Williams et al., 1998). The optimal VPD to carbon assimilation over non-mulched and surface dripping irrigated cotton in arid regions of Australia was $2.2 \mathrm{kPa}$ at the leaf scale (Conaty et al., 2014). This is probably because the sufficient irrigation in cotton field decreased the soil stress and made the cotton experiencing higher values of VPD compared to natural vegetation in arid regions.

The responses of GPP and ET to $T_{a}$ were similar as those to VPD because of the positive correlation between $T_{a}$ and VPD in the field conditions. The increasing VPD was generally accompanied by an increase in $T_{a}$, which directly affected photosynthesis and ET. Many field tests reported a peaked response of ET to VPD when temperature varied (Macfarlane et al., 2004; Whitley et al., 2011). However, the optimum $T_{a}$ or VPD for GPP and ET didn't occur at the same time. The phenomenon of ET and VPD peaked at a higher temperature than GPP did was also reported by Duursma et al. (2014).

\section{Conclusions}

Using the EC method, the carbon and energy fluxes of cotton under drip irrigation with plastic mulch at Wulanwusu site were measured in the growing seasons of 2009, 2010, 2012 and 2013. The changes in carbon fluxes (GPP, NEE and $\mathrm{R}_{\mathrm{es}}$ ) and water flux (ET) were analyzed at different time scales (diurnal, seasonal and inter-annual scales). From June to September, the diurnal GPP, NEE and ET showed a significantly sinusoidal variation and the mean diurnal $\mathrm{R}_{\mathrm{es}}$ remained stable between daytime and nighttime. The maximum peaks of hourly GPP and ET were 21.6 $\mu \mathrm{mol} /\left(\mathrm{m}^{2} \cdot \mathrm{s}\right)$ and $0.49 \mathrm{~mm}$ in July, respectively. The responses of GPP and ET to $\mathrm{R}_{\text {net }}$ showed an asymptotic line with the saturated values of $28.6 \mu \mathrm{mol} /\left(\mathrm{m}^{2} \cdot \mathrm{s}\right)$ and $1.0 \mathrm{~mm}$, respectively. The responses of GPP and ET to VPD and $T_{a}$ were both concave. The optimum values of VPD for GPP and ET were 2.6 and $3.1 \mathrm{kPa}$, respectively; whilst the optimum $\mathrm{T}_{\mathrm{a}}$ were $29.8^{\circ} \mathrm{C}$ and $32.3^{\circ} \mathrm{C}$, respectively. During the growing season, the patterns of GPP, NEE and ET were found to be closely correlated to LAI, and their peaked daily values mostly occurred in the mid- or late-July in the four study periods. The maximum daily GPP in the four years ranged from 11.0 to $15.7 \mathrm{~g} \mathrm{C} /\left(\mathrm{m}^{2} \cdot \mathrm{d}\right)$, and the peaked daily ET was from 5.9 to $6.5 \mathrm{~mm}$. Furthermore, the daily peak values of $R_{\mathrm{es}}$ in the four study periods ranged from 4.3 to $5.0 \mathrm{~g} \mathrm{C} /\left(\mathrm{m}^{2} \cdot \mathrm{d}\right)$. The seasonal sum of GPP for cotton averaged $816.2 \pm 55.0 \mathrm{~g} \mathrm{C} / \mathrm{m}^{2}$, and about $59 \%$ of the total GPP contributed to NEE (averaged at $-478.6 \pm 41.4 \mathrm{~g} \mathrm{C} / \mathrm{m}^{2}$ ). These results illustrated that the mulched cotton functioned as a strong carbon sink during the main growing season (from squaring to harvest stage). It should be noted that from planting until squaring, and then again once the harvest had been gathered, the cotton field diminished to a small carbon source.

\section{Acknowledgements}

This work was supported by the West Light Foundation of the Chinese Academy of Sciences (XBBS201110), the National Natural Science Foundation of China (41101101) and the Chinese Academy of Sciences Key Deployment Project (KZZDEW-08-02-02).

\section{References}

Asner G P, Archer S, Hughes R F, et al. 2003. Net changes in regional woody vegetation cover and carbon storage in Texas Drylands, 1937-1999. Global Change Biology, 9: 316-335.

Aubinet M, Moureaux C, Bodson B, et al. 2009. Carbon sequestration by a crop over a 4-year sugar beet/winter wheat/seed potato/winter wheat rotation cycle. Agricultural and Forest Meteorology, 149: 407-418.

Baldocchi D D. 2003. Assessing the eddy covariance technique for evaluating carbon dioxide exchange rates of ecosystems: past, present and future. Global Change Biology, 9: 479-492.

Chakraborty D, Nagarajan S, Aggarwal P, et al. 2008. Effect of mulching on soil and plant water status, and the growth and yield of wheat (Triticum aestivum L.) in a semi-arid environment. Agricultural Water Management, 95: 1323-1334.

Conaty W C, Mahan J R, Neilsen J E, et al. 2014. Vapour pressure deficit aids the interpretation of cotton canopy temperature response to water deficit. Functional Plant Biology, 41(5): 535-546.

Dağdelen N, Başal H, Yılmaz E, et al. 2009. Different drip irrigation regimes affect cotton yield, water use efficiency and fiber quality in western Turkey. Agricultural Water Management, 96: 111-120.

Deng M. 2009. Studies on water resources strategy in Xinjiang. China Water Resources, 17: 23-27. (in Chinese)

Dong H Z, Li W J, Tang W, et al. 2009. Early plastic mulching increases stand establishment and lint yield of cotton in saline fields. Field Crops Research, 111: 269-275.

Duiker S W, Lal R. 2000. Carbon budget study using $\mathrm{CO}_{2}$ flux measurements from a no till system in central Ohio. Soil \& Tillage Research, 54: 21-30.

Duursma R A, Bartona C V M, Lin Y S, et al. 2014. The peaked re- 
sponse of transpiration rate to vapour pressure deficit in field conditions can be explained by the temperature optimum of photosynthesis. Agricultural and Forest Meteorology, 189-190: 2-10.

Grismer M E. 2002. Regional cotton lint yield, ETc and water value in Arizona and California. Agricultural Water Management, 54: 227-242.

Ham J M, Kluitenberg G J. 1994. Modeling the effect of mulch optical properties and mulch-soil contact resistance on soil heating under plastic mulch culture. Agricultural and Forest Meteorology, 71(3-4): 403-424.

Hou X Y, Wang F X, Han J J, et al. 2010. Duration of plastic mulch for potato growth under drip irrigation in an arid region of Northwest China. Agricultural and Forest Meteorology, 150(1): 115-121.

Hutmacher R B, Krieg D R. 1983. Photosynthetic rate control in cotton: stomatal and nonstomatal factors. Plant Physiology, 73(3): 658-661.

Ibragimov N, Evett S R, Esanbekov Y, et al. 2007. Water use efficiency of irrigated cotton in Uzbekistan under drip and furrow irrigation. Agricultural Water Management, 90: 112-120.

Ko J, Piccinni G. 2009. Characterizing leaf gas exchange responses of cotton to full and limited irrigation conditions. Field Crops Research, 112: 77-89.

Lasslop G, Reichstein M, Papale D, et al. 2010. Separation of net ecosystem exchange into assimilation and respiration using a light response curve approach: critical issues and global evaluation. Global Change Biology, 16: 187-208.

Lei H M, Yang D W. 2010. Seasonal and inter-annual variations in carbon dioxide exchange over a cropland in the North China Plain. Global Change Biology, 16: 2944-2957.

Li F M, Guo A H, Wei H. 1999. Effects of clear plastic film mulch on yield of spring wheat. Field Crops Research, 63: 79-86.

Li F M, Wang J, Xu J Z, et al. 2004. Productivity and soil response to plastic film mulching durations for spring wheat on entisols in the semiarid Loess Plateau of China. Soil \& Tillage Research, 78: 9-20.

Li L H, Chen X, Tol C V C, et al. 2013. Growing season net ecosystem $\mathrm{CO}_{2}$ exchange of two desert ecosystems with alkaline soils in Kazakhstan. Ecology and Evolution, 4(1): 14-26.

Li L, Vuichard N, Viovy N, et al. 2011a. Importance of crop varieties and management practices: evaluation of a process-based model for simulating $\mathrm{CO}_{2}$ and $\mathrm{H}_{2} \mathrm{O}$ fluxes at five European maize (Zea mays L.) sites. Biogeosciences, 8: 1721-1736.

Li Z G, Zhang R H, Wang X J, et al. 2011b. Carbon dioxide fluxes and concentrations in a cotton field in northwestern China: effects of plastic mulching and drip irrigation. Pedosphere, 21(2): 178-185.

Li Z G, Zhang R H, Wang X J, et al. 2012. Growing season carbon dioxide exchange in flooded non-mulching and non-flooded mulching cotton. PLoS ONE, 7(11): e50760, doi: 10.1371/journal. pone.0050760.

Li Z Q, Yu G R, Wen X F, et al. 2005. Energy balance closure at ChinaFLUX sites. Science in China (Earth Sciences), 48: 51-62.

Liu Y, Li S Q, Yang S J, et al. 2013. Diurnal and seasonal soil $\mathrm{CO}_{2}$ flux patterns in spring maize fields on the Loess Plateau, China. Acta Agriculturae Scandinavica (Soil \& Plant Science), 60(3): 245-255.

Macfarlane C, White D A, Adams M A. 2004. The apparent feed-forward responseto vapour pressure deficit of stomata in droughted, field-grown Eucalyptus globulus Labill. Plant, Cell \& Environment, 27: 1268-1280.

Monteith J L. 1995. A reinterpretation of stomatal responses to humidity. Plant, Cell \& Environment, 18: 357-364.

Okuda H, Noda K, Sawamoto T, et al. 2007. Emission of $\mathrm{N}_{2} \mathrm{O}$ and $\mathrm{CO}_{2}$ and uptake of $\mathrm{CH}_{4}$ in soil from a Satsuma mandarin orchard under mulching cultivation in central Japan. Journal of the Japanese Society for Horticultural Science, 76(4): 279-287.

Oweis T Y, Farahani H J, Hachum A Y. 2011. Evapotranspiration and water use of full and deficit irrigated cotton in the Mediterranean environment in northern Syria. Agricultural Water Management, 98: 1239-1248.

Papale D, Reichstein M, Aubinet M, et al. 2006. Towards a standardized processing of Net Ecosystem Exchange measured with eddy covariance technique: algorithms and uncertainty estimation. Biogeosciences, 3: 571-583.

Ramakrishna A, Tam H M, Wani S P, et al. 2006. Effect of mulch on soil temperature, moisture, weed infestation and yield of groundnut in northern Vietnam. Field Crops Research, 95(2-3): 115-125.

Reichstein M, Falge E, Baldocchi D, et al. 2005. On the separation of net ecosystem exchange into assimilation and ecosystem respiration: review and improved algorithm. Global Change Biology, 11: 1424-1439.

Statistic Bureau of Xinjiang Uygur Autonomous Region. 1990-2012. Xinjiang Statistical Yearbook. Beijing: China Statistics Press. (in Chinese)

Suyker A E, Verma S B, Burba G G, et al. 2005. Gross primary production and ecosystem respiration of irrigated maize and irrigated soybean during a growing season. Agricultural and Forest Meteorology, 131: 180-190.

Tang L S, Li Y, Zhang J H. 2005. Physiological and yield responses of cotton under partial rootzone irrigation. Field Crops Research, 94: 214-223.

Tarara J M, Ham J M. 1999. Measuring sensible heat flux in plastic mulch culture with aerodynamic conductance sensors. Agricultural and Forest Meteorology, 95: 1-13.

Vickers D, Mahrt L. 1997. Quality control and flux sampling problems for tower and aircraft data. Journal of Atmospheric and Oceanic Technology, 14: 512-526.

Wang C, Isoda A, Wang P. 2004. Growth and yield performance of some cotton cultivars in Xinjiang, China, an arid area with short growing period. Journal of Agronomy and Crop Science, 190: 177-183.

Wang W, Liao Y C, Guo Q. 2013. Seasonal and annual variations of $\mathrm{CO}_{2}$ fluxes in rain-fed winter wheat agro-ecosystem of Loess Plateau, China. Journal of Integrative Agriculture, 12(1): 147-158.

Wang X F, Ma M G, Huang G H, et al. 2012. Vegetation primary production estimation at maize and alpine meadow over the Heihe River Basin, China. International Journal of Applied Earth Observation and Geoinformation, 17: 94-101.

Whitley R, Zeppel M, Armstrong N, et al. 2008. A modified Jarvis-Stewart model for predicting standscale transpiration of an Australian native forest. Plant and Soil, 305: 35-47.

Whitley R, Macinnis-Ng C, Hutley L B, et al. 2011. Is productivity of mesic savannas light limited or water limited? Results of a simulation study. Global Change Biology, 17: 3130-3149. 
Whitley R, Taylor D, Macinnis-Ng C, et al. 2012. Developing an empirical model of canopy water flux describing the common response of transpiration to solar radiation and VPD across five contrasting woodlands and forests. Hydrological Processes, 27: 1133-1146.

Williams M, Malhi Y, Nobre A, et al. 1998. Seasonal variation in net carbon exchange and evapotranspiration in a Brazillian rain forest. Plant, Cell \& Environment, 21: 953-968.

Wilson K, Goldstein A, Falge E, et al. 2002. Energy balance closure at
FLUXNET sites. Agricultural and Forest Meteorology, 113(1-4): 223-243.

Yong J W G, Wong S C, Farquhar G D. 1997. Stomatal responses to changes in vapour pressure difference between leaf and air. Plant, Cell \& Environment, 20: 1213-1216.

Zhou S Q, Wang J, Liu J X, et al. 2012. Evapotranspiration of a drip-irrigated, film-mulched cotton field in northern Xinjiang, China. Hydrological Processes, 26: 1169-1178. 